\title{
Oração de Paraninfo aos Bacharéis de 1966*
}

\author{
Luís Eulalio de Bueno Vidigal \\ Catedrático de Direito Judiciário Civil na \\ Faculdade de Direito da Universidade de \\ São Paulo.
}

1. Pela quarta vez me depara a fortuna o privilégio de falar a jovens bacharéis no dia de sua formatura. Deveria, essa gloriosa investidura, duas e três vêzes renovada, abrandar, no espírito de quem a recebe, justificado sentimento de orgulho e desvanecimento. No entanto, ao revés disso, agora mais do que nunca, se exacerba no coração de vosso paraninfo a ebriedade do triunfo conquistado a vossa estima e generosidade.

Vossos colegas de há três anos premiaram o professor e cumularam de estímulos o diretor que então iniciava seu mandato. Permiti a vosso paraninfo que veja, na escôlha de hoje, além do prêmio ao professor (que já lhe bastaria), o aplauso ao Diretor e, acima de tudo, vosso reconhecimento à velha alma mater do Largo de São Francisco.

Realmente, de alguns anos a esta parte, vem a mocidade acadêmica, sempre estuante de civismo, buscando alhures, em todo o Brasil, na Academia de Letras, no Supremo Tribunal Federal, no Parlamento, na Imprensa e no Clero, as vozes que lhe hão de dirigir, neste momento, suas palavras de despedida.

Aqui, porém, em nossa venerada escola, ainda têm os mestres o confôrto de vossa confiança e simpatia. Bem

\footnotetext{
* Proferida a 30 de março de 1967.
} 
hajam, pois, os bacharelandos de 1966, por esta confirmada glorificação de nossas arcadas.

2. Iniciáveis vosso curso de Direito Judiciário Civil quando vistes operar-se no país uma dessas profundas transformações que periòdicamente agitam os povos da América Latina. Março de 1964 foi mês de ansiosa expectativa para todos. Éstais bem lembrados de que tôda a escola, mestres e alunos, em dois campos antagônicos, participaram das incertezas e angústias daqueles dias. Subvertida a ordem legal, alterados os quadros de Govêrno, vistes no dealbar do dia $10^{\circ}$ de Abril, muitos de vós com surprêsa e revolta, outros tantos com íntima satisfação, que a imprensa estrangeira qualificava a revolução no primeiro instante, como a vitória da reação contra as fôrças renovadoras sedentas de justiça social. Julgamento surpreendente pela rapidez, e por muitos inesperado, provocou logo das fôrças armadas responsáveis pela situação o esclarecimento de que a revolução não se fizera para garantir os privilégios de quem quer que fôsse.

Para que, então, ela fôra feita?

Eis ai uma boa pergunta que se poderia, com igual pertinência e sem esperança de resposta adequada, fazer a todos os grupos militares que derrubaram governos no Brasil.

Para que, em 15 de Novembro de 1889, foi depôsto o gabinete liberal do Visconde de Ouro Preto? Ninguém sabia. Responda Afronso Arinos de Mello Franco, cujo relato, referto de reminiscências suas e de seus antepassados, tem o sabor de um depoimento pessoal de três gerações. Os republicanos eram pacientes; aguardariam tranqüuilos a morte do Imperador. "Dividido o meio político entre o bacharelismo liberal, o positivismo contista e o espírito de classe militar, não houve, nem poderia haver, orientação intelectual e teórica coerente, no movimento que foi muito mais uma derrota do Império do que uma vitória da República". Certo era apenas que a "sedição 
culminava longo processo de descontentamento e indisciplina no Exército, cujas raizes remotas iam até a guerra do Paraguai".

Para que, em 1930, a Junta Militar derrubou o Presidente Washington Luís?

O pretexto fôra o restabelecimento da autonomia dos Estados. Nunca, no entanto, foi esta mais arranhada do que a partir de então. Os oficiais generais, que empolgaram o poder e deitaram manifesto à Nação, logo cederam o passo aos tenentes que, além da sua inexperiência, nada mais traziam do que os ressentimentos das classes armadas, deflagrados oito anos antes no episódio tragicômico das cartas falsas, que teria sido apenas ridículo se não tivesse custado à Nação os inconseqüentes e deploráveis movimentos de 1922 e 1924, a luta fratricida riograndense em 1923 e as tropelias da Coluna Prestes.

Em 1945, exceção a confirmar a regra, Getúlio Vargas é deposto para se restabelecer no país, com leve tintura de socialização, a república presidencialista e federativa de 1891.

Em 1955, a pretexto de mantê-la, em 1964, para subvertê-la, novamente as fôrças armadas interferem na ordem constitucional vigente.

Para que, então, repetimos, interrompeu-se, em 1964, a regularidade de nossa vida constitucional?

A propaganda oficial nos diz a cada passo que a Revolução tem um programa e o cumprirá, sem desfalecimento, até as últimas conseqüências. $O$ teôr do programa só se vai conhecendo à medida em que a nação defronta os fatos consumados.

A revolução francêsa teve um programa que qualquer estudioso surpreende, na propaganda dos enciclopedistas, nas lutas do parlamento, nas barricadas de 89, e que se desenvolve e realiza mesmo quando, na aparência, abandona seu leito primitivo e o absolutismo retorna à França rom o Consulado e o Império. 
Quem ousaria desconhecer, ou negar, a evidência do programa da revolução russa?

No Brasil, depois de 1930, poderiam os senhores da situação, evocando as duas campanhas de Rui, a campanha da Aliança Liberal, os ensinamentos de Assis Brasil, delinear o programa da revolução, que se resumia em poucas palavras: liberdade, representação e justiça.

Se pretendermos de 1964 deduzir a mesma síntese, lembrando o comício governista do Automóvel Club, a insurreição dos sargentos, a violenta repressão da oficialidade, a pregação dos grandes tribunos da época e os comícios populares, de proporções jamais igualadas no Brasil, a fórmula do programa revolucionário teria de limitar-se a estas palavras: reação conservadora.

Longe de nós a idéia de defender a reação, que nossa indole repele, a inveterada tradição de nossa escola combate e a juventude acadêmica abomina.

As revoluções se justificam sempre que os quadros e sistemas constitucionais, legais, ou consuetudinários impedem as transformações exigidas pelo bem estar coletivo. Hão de ser instantâneas e restabelecer a estabilidade da ordem jurídica. Nós juristas haveremos de sempre combater os processos revolucionários lentos, a se desdobrarem em fases e etapas que nada mais são do que disfarces para os abusos do poder pessoal.

Alguma vez atentastes, jovens bacharéis, no compromisso que o Presidente da República, por disposição constitucional, deve prestar no ato da posse? "Prometo manter, defender e cumprir a Constituição da República". Porque valerá essa promessa feita solenemente perante os representantes da Nação, menos do que as declarações de vontade emitidas sem solenidade por qualquer cidadão em instrumentos particulares? Sabeis que ela foi por três vêzes descumprida sob a alegação de que o "Poder Constituinte da Revolução lhe é intrínseco".

Foi descumprida "porque a Revolução tem promovido reformas e vai continuar a empreendê-las, insistindo em 
seus propósitos de recuperação econômica, financeira, politica e moral do Brasil" e, ainda, "para restabelecer a paz, promover o bem-estar do povo e preservar a honra nacional"

O golpe militar foi uma tomada de posição contra o Govêrno que parecia pretender transformar o Brasil em uma república social sindicalista. $O$ nôvo govêrno, por seu turno, não se limitou a restabelecer o equilíbrio rompido pelo Govêrno anterior e a organizar a Nação para o New Deal.

Muito ao contrário, afastou-se da reação conservadora, que fôra sua bandeira, e proclamou enfáticamente que todos os meios eram bons quando pudessem levar à consecução de seus patrióticos fins.

Bem se revela neste declarado reconhecimento de sobreposição de fins a meios aquela ingênua e reiterada afirmação de que nossa era - a era dos juristas - já passou e de que agora cabe a outros técnicos a tarefa de organizar a Nação.

Sòmente espíritos ignorantes do Direito ou propensos à tirania poderiam ter a pretensão de estabelecer esta necessária hierarquia entre fins e meios. Não aprendestes ainda há pouco que dos três elementos da idéia do direito - bem comum, justiça e segurança - sòmente êstes dois últimos são universalmente válidos?

Há trinta anos, antes da segunda guerra, advertia HuXley profèticamente: "Bons fins só podem ser conseguidos através do emprêgo de meios apropriados. $\mathrm{O}$ fim não pode justificar o meio pela simples e óbvia razão de que os meios empregados determinam a natureza dos fins produzidos". E, refutando LASKY, cita o exemplo do passado: "A dictadura férrea dos jacobinos levou aos massacres das guerras napoleônicas; à imposição da perpetuidade na escravidão militar, ou seja a conscrição sôbre pràticamente tôdas as nações da Europa; e ao despertar daquelas idolatrias nacionalistas que ameaçam a existência de nossa civilização". 
É isto que desejam para nossa pátria os donos da Revolução, privilegiados detentores de todo o saber e tôda a moralidade?

Eliminando, sem embaraço, todos os óbices a sua tranqüila empreitada reformadora, recorrendo a métodos que, suaves na aparência, não deixam de violentar os direitos fundamentais do homem, não estarão lançando as sementes de ódio que, por decênios, virão atormentar os brasileiros?

A Constituição, com que nos aquinhoaram, e que tem seus primeiros dias de vigência, deverá encerrar o ciclo revolucionário. Qual foi, porém, no domínio da segurança e da estabilidade (que, mais do que quaisquer outros fins do Estado, são aptos a propiciar o bem comum), o saldo das atividades revolucionárias?

Deslocou-se do Congresso, em que centenas de deputados e senadores eleitos diretamente pelo povo, representantes do povo brasileiro ou dos Estados federados, reciprocamente se limitavam, para a pessoa do Presidente da República, eleito por um reduzido colégio eleitoral, o poder de decretar o estado de sítio. Basta-lhe, para justificar a medida, a alegação de ameaça de grave perturbação da ordem. E' enquanto durar, o Presidente da República poderá, à sua discrição, determinar detenções, buscas e apreensões domiciliares, e censura de correspondência.

O processo legislativo, que até a Revolução, era privativo do Congresso Nacional, passa agora à competência concorrente do Presidente da República. Em matéria de segurança nacional e finanças públicas, legislará ad referendum do Congresso. Em outras matérias, por delegação do Congresso. Em matérias não especificadas poderá elaborar decretos legislativos. $\mathrm{E}$ em qualquer assunto, o Presidente da República poderá coagir o Congresso a, em quarenta dias, apreciar de afogadilho os projetos que lhe enviar ou com êles se conformar.

Ampliaram-se, por outro lado, em detrimento do Congresso Nacional, os poderes do Presidente da República em matéria de intervenção federal nos Estados. 
As inovações constitucionais foram tôdas no sentido de, à custa das liberdades, da segurança colectiva e da estabilidade das situações jurídicas, permitir-se maior eficiência ao Govêrno na adoção das medidas de interêsse geral. Em suma, sacrificam-se os meios, tendo em vista os fins. E, para nossa inquietação, são exatamente os fins, cujo conteúdo é variável e sujeito às controvérsias e ao choque das opiniões contraditórias, que se entregam à discrição de um só homem.

Nunca, mais do que no presente regime constitucional, a felicidade dos brasileiros tanto dependeu do patriotismo, da clarividência e do espírito de justiça de seu primeiro magistrado. Esperemos que sua ação nos proporcione dias de confiança e tranqüilidade e que seu exemplo inspire salutarmente seus sucessores.

3. No ensino superior, mercê de Deus, a Constituição corrigiu gravissima e errônea tendência que, primeiro em São Paulo e depois em todo o Brasil, vinha exaurindo as parcas possibilidades do erário público no tocante à educação. De trinta anos a esta parte, subiam os compromissos da União no ensino superior e minguava a assistência ao ensino primário. É sábio o novo texto constitucional: $O$ ensino primário é gratuito. $O$ ensino oficial ulterior será gratuito apenas para aqueles que, demonstrando efetivo aproveitamento, provarem insuficiência de recursos. Sempre que possivel, o poder público substituirá o regime de gratuidade pelo de concessão de bolsas de estudo. Ainda bem que a Constituição veio pôr paradeiro ao triste espetáculo de maus estudantes abastados a ocupar, nas escolas oficiais, o lugar de bons e necessitados.

Mantém a União sua competência para traçar as diretrizes e bases da educação nacional. Omite-se, porém, a Constituição quanto ao problema da autonomia universitária. Segundo a atual lei de diretrizes e bases, as universidades deverão gozar de autonomia didática, administrativa, financeira e disciplinar. Valerá, porém, a pena 
dar autonomia à universidade e manietar cada vez mais os institutos que a integram?

Por curiosa evolução inversa, nossa escola tem hoje menos autonomia do que nunca. Há trinta anos, quando a Faculdade de Direito se integrou na Universidade, ninguém sonhava com autonomia das escolas. No entanto, nosso Regulamento, que deveria ser aprovado por lei estadual, foi aprovado em bloco pela Assembléia Legislativa. Francisco Morato, Diretor, encaminhou o projeto. Ernesto LEME, que era então lider da maioria na Assembléia e um dos mais jovens professôres da Faculdade, relata a indignação do Diretor quando lhe submeteram à apreciação algumas emendas surgidas no seio da Assembléia. $\mathrm{E}$ tal era, nesse momento, o prestígio desta escola e de seu diretor, que logo foi afastada a idéia de qualquer emenda e o projeto foi aprovado pela Lei 3.023, que vige até hoje.

Agora, no regime da autonomia universitária, ocorre precisamente o contrário. Quando, há quase quatro anos, assumí a direção da escola, convoquei meus colegas do Conselho Técnico Administrativo e da Congregação para o estudo do novo regulamento. Trabalhando intensamente, conseguimos, apesar de certa colaboração tumultuária, tê-lo aprovado ao fim de seis meses. Supúnhamos que o Conselho Universitário o aprovasse na primeira sessão. Enorme foi nossa decepção ao sabermos que o Projeto não seria tão cedo aprovado e talvez nunca o venha a ser. E consta, ainda, que, se aprovado pelo Conselho Universitário, deverá ser submetido ao Conselho Estadual de Educação.

Que espécie de autonomia è essa que emperra de tal forma a vida da escola, que esta se vê obrigada a adotar métodos alheios, sem lei para os concursos, sem poder disciplinar para funcionários e alunos, sem estatuto dos assistentes e auxiliares de ensino?

Quantas e quantas vêzes recebi vexado a crítica de alunos, principalmente dos que freqüentam outros cursos 
na Universidade, contra nosso anacrônico sistema de ensino?

O curriculo, congesto de matérias, rigido, inflexível. obrigando os alunos ao estudo de assuntos alheios a seu interêsse; os professôres, adstritos às preleções monologadas; os exames, minuciosa e ineptamente regulados por lei de maneira uniforme para tôdas as disciplinas.

Se, realmente, quisermos extrair da idéia da autonomia universitária todos os frutos que pode dar, haveremos de principiar por quebrar a rigidez do currículo, fixando-se número mínimo de disciplinas, algumas obrigatórias e outras de livre escôlha. $O$ professor e seus assistentes deverão cumprir curtos programas fundamentais e orientar os alunos, em pequenas turmas, no estudo e na pesquisa. A verificação do aproveitamento deve ser deixada à discrição de cada professor. Os cursos de pós-graduação e especialização deverão transformar-se em seminários $\mathrm{cm}$ que os alunos trabalhem intensamente.

Bem sabemos nós, por experiência própria, que as resistências às inovações não vêm apenas das insuficiências da legislação. Todos nós, professôres e alunos, somos, por vêzes, transviados por mal compreendido espírito de tradição. De muitos alunos recebo, no início de meus cursos, apelos no sentido de que me não afaste do método tradicional das preleções monologadas, dos exames simplificados, do estudo pelas postilas.

Veneremos a tradição, como fôrça de atração para os jovens, de prestígio para a escola e seus mestres, de sempre renovada afirmação de civismo e dignidade. Saibamos dela fugir quando signifique rotina, marasmo, incapacidade de renovação, conformismo, indolência perante novas idéias e novos caminhos.

4. Uma palavra, ainda, antes da despedida. Poucos de entre vós poderão seguir uma das carreiras privativas dos bacharéis. Tantas são hoje as escolas de direito no Brasil e em São Paulo que a grande maioria há de diri- 
gir-se para outras profissões. Não vos sintais frustrados por essa divisão, nem suponhais por um instante baldados vossos esforços. Tende sempre presente que o curso jurídico, embora inegàvelmente profissional, melhor do que qualquer outro prepara os jovens para as mais variadas atividades. Nos mais altos da vida civil e da vida pública encontrareis sempre em grande maioria ex-alunos de nossa escola. Ide, pois, confiantes, colher o fruto de vossos esforços, prosseguindo, como as gerações que vos precederam, a cobrir de glória as arcadas do convento de São Francisco. 